\title{
Research on the Dimensional Model of Tourist Perceived Value in the Dabie Mountain Ecotourism and Its Empirical Research
}

\author{
Chen Fang \\ Business College, Huanggang Normal University \\ Huanggang City, Hubei Province
}

\begin{abstract}
Based on the view of tourists' experience, this paper builds the conceptual model of tourist perceived value in the Dabie Mountains ecotourism from the four tourist perceived value dimensions of environment, resources, service and cost. Selecting Daofeng Scenic Area as the case study, this paper applies SPSS22.0 and AMOS22.0 analysis tools to dispose of research data, builds the model for analyzing tourist perceived value dimensions, and conducts the measurement research. The results show that the tourist perceived values for the Dabie Mountains ecotourism decreases progressively from the resource perceived value, the environment perceived value, the cost one to the service one. The results indicate the direction for improving the quality of the Dabie Mountains ecotourism from the perspective of tourist perceived values, as well as provide theoretical support and practical guidance for sound and sustainable development of the ecotourism.
\end{abstract}

Keywords-ecotourism; tourist perceived value; Bo Daofeng scenic area

\section{INTRODUCTION}

Taking the ecology principle as the guide, ecological environment and natural resources as the orientation, ecotourism is a marginal ecological engineering and travel activity which can both gain social and economic benefits and protect ecological environment (Lu Yunting, 1996). Ecotourism means a rational development and utilization of tourist attractions under the premise of protecting natural resources, emphasizing the understanding, enjoyment and protection of natural resources on the basis of respect for nature. In recent years, with the economic development and social progress, people in the pursuit of material life begin to focus on spiritual enjoyment and environmental quality, so ecotourism industry has shown a rapid development trend. With rich ecotourism resource, the Dabie Mountains has become the preferred ecotourism destination for tourists from neighboring provinces and cities [1].

At present, research on the development of ecotourism scenic spots mainly focuses on the view of ecological resources and scenic area managers, less from the perspective of tourists, let alone from the perspective of tourist perceived values. With Bo Daofeng Scenic Area as the case study, from the perspective of tourist experience, this paper can identify the

Fund Project: Open Project of Dabie Mountains Tourism Economy and Cultural Research Center (03201715203). influencing factors of tourist perceived values in the Dabie Mountains ecotourism to reveal the intrinsic dimension of the values, and to provide theoretical support and practical guidance for the development of Dabie Mountain eco-tourism.

\section{THE CONCEPTUAL MODEL OF TOURIST PERCEIVED VALUE FOR THE DABIE MOUNTAINS ECOTOURISM}

\section{A. Tourist Perceived Value Content}

Zeithaml (1988) proposed the theory of customer perceived value and thought that customer perceived value is the subjective cognitive evaluation when consumer comparing the experienced benefits and costs after consumption of services or products; on the basis of that theory, tourism scholars put forward tourist perceived value. Tourist perceived value is the comprehensive evaluation manifesting the satisfaction degree of desire and expectation from consumption experience, knowledge and preference formed in travel as well as product attributes, performance and input in travel and consumption (Huang Yinghua, Huang Fucai, 2007). Tourist perceived value is a tourist's comprehensive evaluation of tourism services or services to meet tourist expectations in a certain tourism situation on the basis of experienced benefits and loss by a tourist; good tourist perceived values is the foundation for ecotourism attractions to attract tourists.

\section{B. The Conceptual Model Design of Tourist Perceived Value for the Dabie Mountains}

Tourist perceived value is based on customer value theory, but the perceived experience of tourists in travel is different from tangible products or services. Tourism products are the combination of products and services that tourists perceive in the course of tourism, including all perceived experience indexes. According to the theory of consumer behavior, tourist perceived value is influenced by both tourism marketing stimulus and tourist learning experience. First of all, before the tour of ecotourism scenic spots [2], visitors will form a specific psychological expectations under the marketing stimulus; secondly, expected experience goals and value expectations produced by tourists's study would become the actual perceived value after the tour. Based on the existing studies of tourist perceived value (Li Hai'e, Xiong Yuanbin, 2014) and the experiential view angle, this paper builds the conceptual model 
of tourist perceived value in the Dabie Mountains ecotourism from the four tourist perceived value dimensions of environment, resources, service and cost.

\section{EMPIRICAL RESEARCH ON TOURIST PERCEIVED VALUE FOR THE DABIE MOUNTAINS ECOTOURISM}

\section{A. Questionnaire Development}

On the basis of the existing research results (Wang Li et al., 2014), the tourist perceived value questionnaire for the Dabie Mountains ecotourism takes shape by analysis and summary of developed tourist perceived value questionnaire and tourist interviews, as well as by combination with tourist needs and consumption features of the Dabie Mountains ecotourism. In order to improve the feasibility and effectiveness of the questionnaire, the author in the middle of April 2017 visited Bo Daofeng scenic area for field observation and small-scale visitor interviews, as well as modified and improved the questions for forming the final questionnaire [3].

The research content is divided into two parts. The first part includes sex, age, occupation and other general tourist information; the second part is the tourist perceived value measurement scale, whose items employ the Likert 5-point scale on a continuum from strongly agree to strongly disagree, in which respondents grade the 20 items on tourist perceived value for the Dabie Mountains ecotourism.

\section{B. Questionnaire Survey and Sample Analysis}

The research team conducted a field survey of Bo Daofeng scenic area in May 2017 twice, and commissioned a tour guide to assist in completing the survey, using on-site distribution and recovery to improve the questionnaire recovery and research quality. 527 out of total 590 questionnaires were recovered, the recovery rate $89.3 \%$; excluding invalid ones, 489 valuable questionnaires were recovered, the effective rate $82.9 \%$. In effective samples, women accounted for $54.2 \%$ while men $45.8 \%$, the former bigger than the latter; the number of respondents aged from 25 to 40 is the biggest, $74.7 \%$ of the total survey population; tourists generally have high education background, undergraduate and postgraduate reaching $55.4 \%$.

\section{Analysis of Perceived Value Factors}

\section{1) Exploratory Factor Analysis}

SPSS22.0 is used to conduct the exploratory factor analysis on measurement indexes of tourist perceived value dimension. An exploratory factor analysis was conducted on 152 valid questionnaires from the first formal survey. First, test reliability and validity. The Cronbach confidence value of the holistic sample is 0.815 , and in the exploratory study, the Cronbach confidence value is greater than or equal to 0.8 , which is considered to have a good consistency reliability (Straub, 1989), so this research has a dependable sample reliability. KMO and Bartlett's test of sphericity are used for validity test, and KMO value is 0.717 greater than 0.7 , indicating that the sample is suitable for factor analysis. Bartlett's test of sphericity with a $\mathrm{P}$ value of less than 0.05 also validated the sample's suitability for factor analysis.

Secondly, the common factor is extracted by principal component analysis and rotated by varimax, and the common factor is chosen according to the principle that the eigenvalue is greater than or equal to 1 . The indicator factor choose 0.5 as factor loading intercept point, and the items with loads of multiple factors greater than 0.4 or any factor load less than 0.5 are deleted [4]. Thus, delete resource perceived value factors of pleasant ecological environment and rich tourism activities, environment perceived value factors of orderly traffic around scenic spots the traffic and catering with regional characteristics, as well as cost perceived value factor of reasonable catering prices. Then conduct factor analysis of the sample data of the remaining 15 tourist perceived value scales (see Table 1). The analysis results show that the KMO value is 0.714, suitable for factor analysis; $\mathrm{P}$ value of Bartlett's test of sphericity is less than 0.05 , suitable for factor analysis. 4 common factors whose eigenvalues are greater than 1 are extracted by the maximum variance cross rotation, and the 4 common factors explain $63.636 \%$ information, more than $60 \%$, the minimum standard for the variance contribution rate, which shows that the extraction of 4 common factors is acceptable. 
TABLE I.

FACTOR ANALYSIS OF COMMON FACTOR LOADING, EIGENVALUE AND CONTRIBUTION RATE AFTER

\begin{tabular}{|c|c|c|c|c|c|}
\hline Factor & Indicator & $\begin{array}{l}\text { Factor } \\
\text { loading }\end{array}$ & Total & $\begin{array}{c}\text { Variance } \\
\text { contribution }(\%)\end{array}$ & $\begin{array}{c}\text { Accumulated } \\
\text { Variance } \\
\text { Contribution(\%) }\end{array}$ \\
\hline \multirow{6}{*}{$\begin{array}{l}\text { Resource } \\
\text { perceived } \\
\text { value F1 }\end{array}$} & Biodiversity X11 & 0.635 & \multirow{6}{*}{4.001} & \multirow{6}{*}{26.675} & \multirow{6}{*}{26.675} \\
\hline & $\begin{array}{l}\text { Rich natural landscape } \\
\text { X12 }\end{array}$ & 0.744 & & & \\
\hline & $\begin{array}{c}\text { Landscapes rich in } \\
\text { geographical features } \\
\text { X13 }\end{array}$ & 0.647 & & & \\
\hline & $\begin{array}{c}\text { High ecological } \\
\text { landscape ornamental } \\
\text { value X14 }\end{array}$ & 0.534 & & & \\
\hline & $\begin{array}{l}\text { Distinctive tourism } \\
\text { souvenirs } 8 \mathrm{X} 15\end{array}$ & 0.717 & & & \\
\hline & $\begin{array}{c}\text { Reasonable scenic } \\
\text { facilities layout X16 }\end{array}$ & 0.568 & & & \\
\hline \multirow{5}{*}{$\begin{array}{l}\text { Environment } \\
\text { perceived } \\
\text { value F2 }\end{array}$} & $\begin{array}{l}\text { Clear scenic spot and } \\
\text { landscape signs X21 }\end{array}$ & 0.539 & \multirow{5}{*}{2.799} & \multirow{5}{*}{18.659} & \multirow{5}{*}{45.334} \\
\hline & $\begin{array}{c}\text { Convenient and } \\
\text { comfortable tourism } \\
\text { vehicle } \mathrm{X} 22\end{array}$ & 0.652 & & & \\
\hline & $\begin{array}{l}\text { High sense of security } \\
\text { in tour X23 }\end{array}$ & 0.664 & & & \\
\hline & $\begin{array}{l}\text { Good hygienic state of } \\
\text { the scenic area X24 }\end{array}$ & 0.684 & & & \\
\hline & $\begin{array}{c}\text { Comfortable scenic } \\
\text { sightseeing environment } \\
\text { X25 }\end{array}$ & 0.648 & & & \\
\hline \multirow{2}{*}{$\begin{array}{l}\text { Service } \\
\text { perceived } \\
\text { value F3 }\end{array}$} & $\begin{array}{l}\text { Good service of scenic } \\
\text { staff X31 }\end{array}$ & 0.654 & \multirow[b]{2}{*}{1.439} & \multirow[b]{2}{*}{9.596} & \multirow[b]{2}{*}{54.930} \\
\hline & $\begin{array}{c}\text { Convenient } \\
\text { accommodation around } \\
\text { scenic spots X32 }\end{array}$ & 0.638 & & & \\
\hline \multirow{2}{*}{$\begin{array}{l}\text { Cost perceived } \\
\text { value } \mathrm{F} 4\end{array}$} & $\begin{array}{l}\text { Reasonable scenic spots' } \\
\text { entrance tickets X41 }\end{array}$ & 0.667 & \multirow[t]{2}{*}{1.306} & \multirow[t]{2}{*}{8.706} & \multirow[t]{2}{*}{63.636} \\
\hline & Cost-effective tour X42 & 0.698 & & & \\
\hline
\end{tabular}

2) Confirmatory Factor Analysis

According to the exploratory factor analysis, 4 common factors and their corresponding measurement indexes were used to establish the verification model of tourist perceived value measurement dimension by AMOS22.0 software, and the data were analyzed as 336 valid questionnaires recovered from the second survey. The results of the confirmatory factor analysis show that $\mathrm{x} 2$ / $\mathrm{df}$ is 2.633 (degree of freedom $\mathrm{df}=84$, chi-square $\mathrm{x} 2=221.168$ ), between 2.0 and 5.0, and less than 3.0; absolute matching index RMR, GFI, RMSEA are 0.036, $0.921,0.052$ respectively, reaching the acceptable range of the structural model (Han Jing, Zhang Yin, 2016). The fitness of the model intrinsic structure is good, and factor loading (normalized path coefficient) of the observed variables is greater than 0.5 , and the estimated values of all parameter statistics reach a significant level. The indicators of the comprehensive confirmatory factor analysis has reached the desired level [5], if the model is assumed to fit adaptation criteria.

\section{3) Analysis of Tourist Perceived Value}

In order to further understand tourist perceived value and evaluation of its dimensional perceived experience, the mean value method is utilized to describe the average level of tourists' perception assessment of the Dabie Mountains ecotourism. In general, the Likert scale rating scores of 1 to 2.4 2.5 to 3.4 and 3.5 to 5 , respectively represent opposition, neutrality and approval [6]. By comparing the analysis results, mean value of tourist perceived value dimension is got (see Table 2). From Table 2, it can be seen that tourists have high satisfaction with tourist perceived value in the Dabie Mountain 
ecotourism, but low satisfaction with cost and service perceived values. The mean value of tourists' overall satisfaction rate is 3.41 , which is in the threshold of neutrality and satisfaction. From the perspective of tourist experience, the Dabie Mountain ecotourism should further improve environment, service and cost to enhance tourist perceived value [7].

TABLE II. TOURIST PERCEIVED VALUE DIMENSION MEAN VALUE

\begin{tabular}{|c|c|c|}
\hline $\begin{array}{c}\text { Tourist perceived value } \\
\text { dimension }\end{array}$ & $\begin{array}{c}\text { Mean } \\
\text { value }\end{array}$ & $\begin{array}{c}\text { Standard } \\
\text { deviation }\end{array}$ \\
\hline $\begin{array}{c}\text { Resource perceived value } \\
\text { F1 }\end{array}$ & 3.755 & 0.768 \\
\hline $\begin{array}{c}\text { Environment perceived } \\
\text { value F2 }\end{array}$ & 3.349 & 0.589 \\
\hline $\begin{array}{c}\text { Service perceived value F3 } \\
\text { Cost perceived value F4 }\end{array}$ & 3.1670 & 0.608 \\
\hline Overall satisfaction & 3.410 & 0.418 \\
\hline
\end{tabular}

\section{CONCLUSION AND DISCUSSION}

This paper builds the conceptual model of tourist perceived value for the Dabie Mountain ecotourism, and takes Bo Daofeng scenic area as an example to carry on the empirical research. The results show that tourist perceived value for the Dabie Mountains include resources, environment, service and cost, discovering successive decrease from resource perceived value, environment perceived value, cost perceived value to service perceived value by the mean value. According to the results, effect analysis of the Dabie Mountain ecotourism is derived; tourists' resource perceived value is high, while their service and cost perceived values are low, so it is necessary for the Dabie Mountain ecotourism scenic area to not only continuously upgrade the level of hardware facilities, but also focus on improving the quality of software services and tourists' overall perception and evaluation of the Dabie Mountain ecotourism.
The practical significance of this research has two main aspects. First, it is of great significance for the development and protection of the ecological tourism resources ontology in the Dabie Mountains. That tourists' satisfaction with the evaluation of resource perceived value fully illustrates the tourism resource ontology is the basic requirement of tourists' perception experience; establishment of a scientific and rational ecological environment development and protection system, and maintainment of natural harmonious ecological scenery are the ecological safeguard for sustainable development of the Dabie Mountain ecotourism. Second, the direction is pointed out for improving the quality of the Dabie Mountain ecotourism from the perspective of tourist perceived value. Since tourist perceived value for the Dabie Mountain ecotourism possesses both functionality and emotionality, and less satisfaction of tourists for service and cost perceived values has a direct band effect on the ecotourism scenic spot image and reputation, tourism operators should emphasize tourist perception and evaluation on the quality of service, strive to strengthen the service concept, and continuously improve the level of service.

\section{REFERENCES}

[1] Lu Yunting. Ecotourism and Sustainable Tourism Development [J]. Economic Geography, 1996 (1): 106-112.

[2] Zeithaml V A. Consumer Perceptions of Price, Quality, and Value: A Means-End Model and Synthesis of Evidence[J].Journal of Marketing, 1988, 52(3):2-22.

[3] Huang Yinghua, Huang Fucai. Tourist Perceived Value Model, Measurement and Empirical Research [J]. Tourism Tribune, 2007, 22 (8): 42-47.

[4] Li Hai'e, Xiong Yuanbin. Tourist Perceived Value For Museums in the Background of Free Admission-A Case Study of Hubei Provincial Museum [J]. Hubei Social Sciences, 2014 (12): 73-78.

[5] Wang Li, Zhang Hongmei, Lu Lin, et al. Study on Tourist Perceived Value of Wetland Parks [J]. Tourism Tribune, 2014, 29 (6): 87-96.

[6] Straub D W. Validating instruments in MIS research[J].Mis Quarterly, 1989, 13(2):147-169.

[7] Han Jing, Zhang Yin.The Comparative Study on the Tourist Perceived Value Intervention Methods for TCM Evaluation of Recreational Value Influence-A Case Study of Zhangguying Village in Hunan Province [J]. Tourism Science, 2016, 30 (5): 24-36. 